\title{
Thoracic and heart biometrics of non-anesthetized agouti (Dasyprocta primnolopha Wagler, 1831) measured on radiographic images ${ }^{1}$
}

\author{
Anaemilia das N. Diniz², José R. da Silva Júnior ${ }^{3}$, Carlos E. Ambrósio ${ }^{4}$, João M. de \\ Sousa $^{5}$, Videlina R. de Sousa ${ }^{2}$, Maria A.M. Carvalho ${ }^{6}$, Dayana M. Nascimento ${ }^{7}$ \\ and Flávio R. Alves ${ }^{6 *}$
}

\begin{abstract}
Diniz A.N., Silva Júnior J.R., Ambrósio C.E., Sousa J.M., Sousa V.R., Carvalho M.A.M., Nascimento D.M. \& Alves F.R. 2013. Thoracic and heart biometrics of non-anesthetized agouti (Dasyprocta primnolopha Wagler, 1831) measured on radiographic images. Pesquisa Veterinária Brasileira 33(3):411-416. Departamento de Morfisiologia Veterinária, Curso de Medicina Veterinária, Universidade Federal do Piauí, Campus Universitário Ministro Petrônio Portella, Bairro Ininga, Teresina, PI 64049-550, Brazil. E-mail: flavioribeiro@ufpi.edu.br

The agouti is a species intensively hunted throughout the Amazon and the semi-arid regions of northeastern Brazil. Considering the current trend in conservation management of wild species, the aim of this study was to determine the morphometric reference to the heart of agouti raised in captivity, based on thoracic and cardiac measurements in these animals. Thirty adult agoutis, 1 to 3 years of age, without clinical signs of cardiac disease were selected. The animals were physically restrained and radiographies in laterolateral (LL) and ventrodorsal (VD) recumbence were produced. The following measures were taken: the apicobasilar length of the heart (at the most cranial height of the Carina region to the heart apex) $(A B)$, maximum width of the heart perpendicular to $A B(C D)$, heart inclination angle (AIC), trachea inclination angle (AIT), distance from the right heart wall (DPTd), distance from the left heart wall (DPTe) and vertical depth of the thorax, and the ventral face of the vertebral column to the dorsal border of the sternum at the level of the trachea bifurcation $(\mathrm{H})$. The ratios between $\mathrm{AB} / \mathrm{CD}, \mathrm{AB} / \mathrm{H}$ and $\mathrm{CD} / \mathrm{H}$ were also analyzed. To calculate the vertebral heart scale (VHS), the $\mathrm{AB}$ and $\mathrm{CD}$ measurements were laid over the thoracic vertebra starting at T4. Radiographic evaluation showed values consistent with those reported in small animals and some wild and exotic species. The main biometric values in the chest cavity and heart of agouti are arranged as follows: (1) The ratios between $\mathrm{AB} / \mathrm{H}$ ratio and $\mathrm{CD} / \mathrm{H}$ were not sensitive for identifying heart increases ( $>0.05$ ), while the ratio $A B / C D$ was more sensitive in this identification ( $p<0.05$ ); (2) AIC: $21.2 \pm 6.4^{\circ}$ (mean between male and famale); (3) AIT for males and females: $9.93 \pm 3.23^{\circ}$ and $8.4 \pm 3.94^{\circ}$; (4) DPTd and DPTe for males: $0.97 \pm 0.40 \mathrm{~cm}$ and $0.7 \pm 0.30 \mathrm{~cm}$; (5) DPTd and DPTe for females: $1.12 \pm 0.42 \mathrm{~cm}$ and $01.02 \pm 0.43 \mathrm{~cm}$; (6) VHS for males and females: $7.75 \pm 0.48 \mathrm{v}$ e $7.61 \pm 0.34 \mathrm{v}$; (7) The caudal vena cava (CVC) was visualized dorsal-cranially and located right of the midline. The data obtained allowed the acquisition of the first reference values for biometry
\end{abstract}

\footnotetext{
${ }^{1}$ Received on July 25, 2012.

Accepted for publication on January 30, 2013.

${ }^{2}$ Programa de Pós-Graduação em Ciência Animal, Universidade Federal do Piauí (UFPI), Campus Universitário Ministro Petrônio Portella, Bairro Ininga, Teresina, PI 64049-550, Brazil.

${ }^{3}$ Departamento das Clínicas, Curso de Medicina Veterinária, Universidade Estadual do Maranhão (UEMA), Campus Paulo VI s/n, São Luís, MA 65055-310, Brasil.

${ }^{4}$ Departamento de Medicina Veterinária, Faculdade de Zootecnia e En-
}

genharia de Alimentos, Universidade de São Paulo (USP), Av. Duque de Caxias Norte 225, ZAB, Pirassununga, SP 13635-900, Brazil.

${ }^{5}$ Depto Clínica e Cirurgia Veterinária, Curso de Medicina Veterinária, Universidade Federal do Piauí (UFPI), Bairro Ininga, Teresina, PI.

${ }^{6}$ Depto Morfofisiologia Veterinária, Curso de Medicina Veterinária, UFPI, Campus Universitário, Bairro Ininga, Teresina, PI. *Corresponding author: flavioribeiro@ufpi.edu.br

${ }^{7}$ Curso de Medicina Veterinária, UFPI, Campus Universitário, BR 135 Km 3, Bom Jesus, PI 64900-000, Brazil. 
of the heart of agoutis, contributing to better understanding of cardiac morphology and identification of cardiomyopathy in these animals.

INDEX TERMS: Dasyprocta primnolopha, thoracic biometry, cardiology, VHS, wild animals, Brazilian cerrado.

RESUMO.- [Biometria torácica e cardíaca de cutias não anestesiadas (Dasyprocta primnolopha Wagler, 1831) mensuradas em imagens radiográficas.] A cutia é uma espécie intensamente caçada em toda a Amazônia e nas regiões semi-áridas do Nordeste do Brasil. Considerando a tendência atual em gestão de conservação das espécies selvagens, o objetivo deste estudo foi determinar referências morfométricas para o coração de cutia criadas em cativeiro, com base em medições torácicas e cardíacas desses animais. Foram selecionados 30 cutias adultas, sem sinais clínicos de doença cardíaca, com idade entre 1 a 3 anos. Os animais foram contidos fisicamente e realizadas projeções radiográficas laterolaterais e (LL) e ventrodorsais (VD). As seguintes medidas foram tomadas: 0 comprimento apicobasilar do coração (na altura mais cranial da região carina até o ápice do coração) (AB); a largura máxima coração perpendicular a $A B(C D)$; o ângulo de inclinação do cardíaca (AIC); ângulo de inclinação da traquéia (AIT); a distância a partir da parede direita do coração (DPTd); a distância a partir da parede esquerda do coração (DPTe) e profundidade vertical do tórax, da face ventral da coluna vertebral até à borda dorsal do esterno, no nível da bifurcação da traqueia $(\mathrm{H})$. As relações entre $\mathrm{AB} / \mathrm{CD}, \mathrm{AB} / \mathrm{H}$ e CD/H também foram analisadas. Para calcular o "vertebral heart scale" (VHS), as medidas $\mathrm{AB}$ e $\mathrm{CD}$ foram colocadas sob as vértebras torácicas a partir de T4. A avaliação radiográfica demonstrou valores consistentes com aqueles relatados em pequenos animais e algumas espécies selvagens e exóticos. Os principais valores biométricos mensurados na cavidade torácica e cardíaca da cutia, estão dispostas da seguinte forma: (1) As relações entre $\mathrm{AB} / \mathrm{H}$ e $\mathrm{CD} / \mathrm{H}$ não foram sensíveis para identificar aumento do coração (p>0,05), enquanto a proporção $\mathrm{AB} / \mathrm{CD}$ foi mais sensível nesta identificação (p <0,05); (2) AIC: $21,2 \pm 6.4^{\circ}$ (média entre machos e fêmeas); (3) AIT para machos e fêmeas: $9.93 \pm 3.23^{\circ}$ and 8.4 $\pm 3.94^{\circ}$; (4) DPTd e DPTe para os machos: 0,97 $\pm 0,40 \mathrm{~cm}$ e 0,7 $\pm 0,30$, (5) DPTd e DPTe para as fêmeas: $1,12 \pm 0,42$ e 01,02 $\pm 0,43$; (6) VHS para machos e fêmeas: $7.75 \pm 0.48 \mathrm{v}$ e $7.61 \pm 0.34 \mathrm{v}$; (7) A veia cava caudal (CVC) foi visualizada dorso-cranialmente e localizada à direita da linha média. Os dados obtidos permitiram a obtenção dos primeiros valores de referência para a biometria do coração de cutias, contribuindo para uma maior compreensão da morfologia cardíaca e identificação de cardiomiopatia nestes animais.

TERMOS DE INDEXAÇÃO: Dasyprocta sp., biometria torácica, cardiologia , VHS, animais silvestres, cerrado brasileiro.

\section{INTRODUCTION}

Great effort has been made in the attempt to obtain greater knowledge on the biology of wild species, especially those threatened with extinction (Alimurung et al. 1980, Leal et al. 2005, Sampaio \& Batista 2004). Wild rodents such as the paca (Agouti paca), capibara (Hydrochaeris hydrochae- ris), rock cavy (Kerodon rupestris), and agouti (Dasyprocta aguti) are species intensely hunted throughout the Amazon and the semi-arid regions of north-eastern Brazil, and are an important option for animal protein consumption for the local population (Bodmer et al. 1997, Nogueira-Filho \& Nogueira 2000, Ribeiro et al. 2007).

Among these animals, the agouti is of both zootechnical and conservationist interest (Lopes et al. 2004. Pinheiro et al. 1989). The establishment of conservation units and commercial breeding farms has stimulated studies to acquire biological data of the species, especially the characteristics of reproductive, health and good management, to ensure its survival in captivity (Berllago \& Cerqueira 1994, Redford 1997, Ferraz et al. 2010).

Although already discussed, establishing clinical normality criteria for wild rodents still requires greater studies on their physiology and organic responses (Osofsky et al. 2001, Crissey et al. 2004, Fox et al, 2008).

Among the parameters assessed, access to the heart function is important data to define the homeostatic balance in wild species (Heatley 2009, Black et al. 2011). Investigation by image is widely used in cardiologic assessments in veterinary medicine (Ware 2007). However, reference values have not yet been fully established for most wild species, and there is little information in the literature to support standardization of access techniques to the heart function and suggest alterations in this organ for these animals (Stepien et al. 1999, Gardner 2007, Estrada et al. 2009, Onuma 2009, Black 2011).

The thoracic cavity radiographic exam is a quick and non-invasive assessment that allows valuable information to be obtained on the lung fields, heart size and vascularization. For dogs, Hamlin (1968) established guidelines regarding the normal heart size, situated between 2.5 and 3.5 intercostal spaces. Although they are used in the routine of radiographic exams, these are limited especially in the variations of the heart axis, thoracic shape, inspiratory phase and rib overlap.

To overcome these limitations, Buchanan \& Bücheler (1995) proposed the existence of a significant correlation between heart size and thoracic vertebra length, a method that they called the vertebral heart scale (VHS). Many studies have shown that VHS makes an important contribution in determining alterations in heart size in domestic species such as dogs and cats (Ghadiri et al. 2008, Leal et al. 2005). However, the use of these and other measuring techniques is still little understood to identify alterations in the heart anatomic conformation among wild species (Gardner et al. 2007, Estrada et al. 2009, Black et al. 2011).

Considering the need for quick access to information on the heart function, still scarce for wild species, and considering the existing literature to estimate this function by VHS and thoracic biometry, the objective of the present stu- 
dy was to define heart radiographic normality parameters for healthy agouti (Dasyprocta prymnolopha Wagler, 1831) without using chemical restraint, kept in captivity, seeking to contribute to acquiring data that can be used as normal parameters of the species and help to identify possible alterations.

\section{MATERIALS AND METHODS}

\section{Animals}

Thirty agouti (Dasyprocta primnolopha, Wagler 1831), 1 to 3 years of age, weighing from 1.670 to $2.950 \mathrm{~kg}$ were used and divided into two groups of 15 males and 15 females separated in collective stalls. The animals came from the Wild Animal Study and Preservation Nucleus (Núcleo de Estudos e Preservação de Animais Silvestres) - NEPAS (Registration Certificate IBAMA/ PI № 02/08-618) at the Agrarian Science Centre (CCA) of the Federal University of Piauí (UFPI). They were healthy at clinical examination and the hematological profile was normal (Ribeiro et al. 2008). The food management consisted of commercial feed (minimum crude protein $12 \%$, ether extract $1.5 \%$, fibrous material $12 \%$, calcium $1.3 \%$ and phosphorus $0.4 \%$ ) in addition to corn, regional fruit and vegetables and water ad libertum. The experimental protocol was approved by the Committee of Ethics in Animal Experimentation (CEEA) of the Federal University of Piauí-UFPI (Protocol 0117/2010) and authorized by the Authorization and Information in Biodiversity System- SISBIO - ICMBio/IBAMA (Protocol 26101-1).

The animals were restrained physically and kept in right lateral recumbence on a semiological examination table (M-351) with the thoracic limbs raised cranially, pelvic limbs lowered caudally. The heart and respiratory function was assessed using a stethoscope (Littmann Cardiology III) to observe the normal hyphonesis of the heart noises, respiratory frequency and sonority of the lung fields (current volume normality).

\section{Radiographic exam}

Radiographic images were obtained in ventrodorsal projection (VD) and latero lateral projection (LL) of the thoracic region of each animal, using the same restraint method used when assessing the heart and respiratory function. The thoracic limbs were tractioned cranially, to prevent the biceps muscles from overlapping the lung fields. An INTECAL CR-7 mobile x-ray apparatus was used, calibrated with a $1 \mathrm{~m}$ focus-film distance and $45 \mathrm{kVp}$ and $m A s$ exposure techniques. The images were acquired on a metal $18 \mathrm{x} 24 \mathrm{~cm}$ radiographic chassis (Foto Med). The films were developed and fixed in a Microtec MX-2 automatic processor. All the material and apparatus were from the Diagnosis by Image Sector of the University Veterinary Hospital (HDU) of the Federal University of Piauí. The radiographic images were digitalized and documented for later assessment.

The radiographic images were first analyzed for the lung radiographic characteristics observable for the species by a veterinary radiologist (DVM, Ph.D.). Later the morphometric assessments of the thoracic cavity were performed.

Figure 1 shows the measurements taken. They were the apicobasilar length of the heart (at the most cranial height of the Carina region to the heart apex) $(\mathrm{AB})$; maximum width of the heart perpendicular to $\mathrm{AB}(\mathrm{CD})$; heart inclination angle (AIC); trachea inclination angle (AIT); distance from the right heart wall (DPTd);
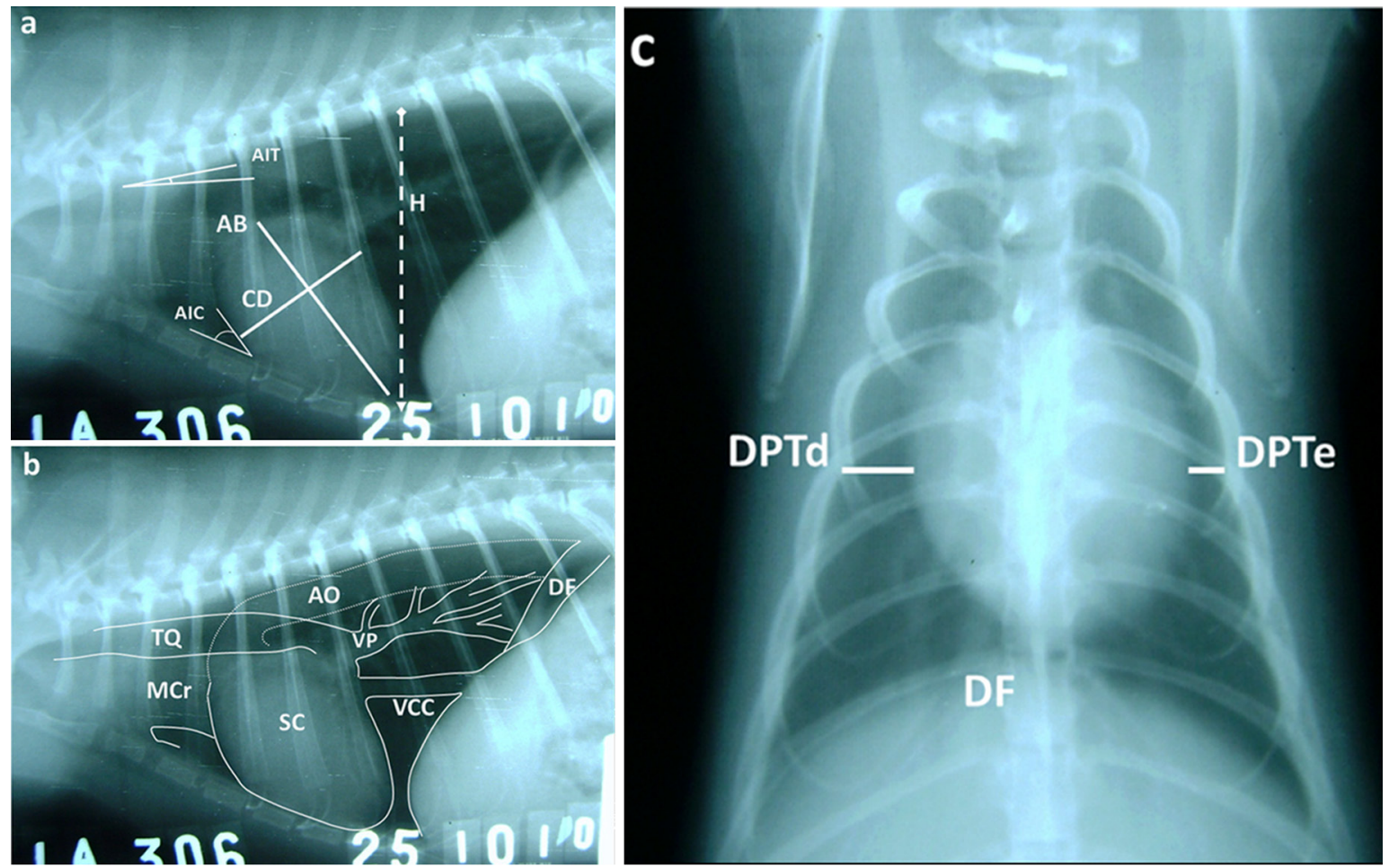

Fig.1. Laterolateral radiography of a clinically normal agouti (Dasyprocta primnolopha, Wagler 1831). (a) Shows the measurements taken to assess the heart size. (b) A schematic model of the topography of the heart, aorta, trachea and vascular distribution. (c) Ventral dorsal radiography illustrating the measurements of the distances from the heart wall. AB: apicobasilar length of the heart; $C D$ : maximum width of the heart perpendicular to $A B$; AIC: heart and inclination angle; AIT: trachea inclination angle; DPTd: distance from the right heart wall; DPTe: distance from the left heart wall; H: thorax vertical depth; SC: heart Silhouette; TQ: trachea; MCr: Cranial mediastinum cranial; AO: Aorta; VP: pulmonary vessels; VCC: Caudal vena cava; DF: diaphragm. 
distance from the left heart wall (DPTe) and vertical depth of the thorax, from the ventral face of the vertebral column to the dorsal border of the sternum at the level of the trachea bifurcation $(\mathrm{H})$. The ratios between $\mathrm{AB} / \mathrm{CD}, \mathrm{AB} / \mathrm{H}$ and $\mathrm{CD} / \mathrm{H}$ were also analyzed. To calculate the vertebral heart scale (VHS), the $\mathrm{AB}$ and $\mathrm{CD}$ measurements were laid over the vertebra starting at T4. Figure $1 \mathrm{~b}$ shows a schematic model of the topography of the heart, aorta, trachea and lung vessels. Figure 1c shows the measurements on the ventrodorsal projection.

\section{Statistical analysis}

The data were submitted to the normal error distribution test (Shapiro-Wilk and Kolmogorov-Smirnov test) and later in the means of the male and female groups were analyzed by the student t-test prepared for parameter interpretation, considering a confidence interval of $5 \%(p<0.05)$.

\section{RESULTS}

The agouti heart was inclined cranially at an angle (AIC) of $21.2 \pm 6.4^{\circ}$. Comparison of the males $\left(16.73 \pm 7.12^{\circ}\right)$ and females $\left(22.8 \pm 8.5^{\circ}\right)$ showed that the males presented smaller AIC and there was significant difference $(\mathrm{p}=0.01$. $\mathrm{p}<0.05$ ). The heart was located in all the animals in the mid mediastinum, between the third and sixth intercostal spaces (LL and VD projections). The males presented $0.97 \pm 0.40$ $\mathrm{cm}$ (DPTd) and $0.7 \pm 0.30$ (DPTe) distance from the thoracic wall, while the females presented values of $1.12 \pm 0.42$ (DPTd) and $1.02 \pm 0.43$ (DPTe), showing that the heart of the males was located closer to the left thoracic wall, compared to the females, with significant difference among males and females for this variable $(p=0.048 . p<0.05)$. However, no difference was observed between the DPTd for males and females ( $p=0.33 . p>0.05)$.

The caudal vena cava (CVC) and the lung vessels were little visualized in all the radiographs. When identified, the lung vessels presented dichotomized pattern, starting from the lung hilum towards the caudal lobes and the CVC was inclined dorsal-cranially (LL projection) and situated slightly to the right of the midline (VD projection). The tra-

Table 1. Normal values of heart measurements of agouti (Dasyprocta primnolopha, Wagler 1831) in latero lateral and ventral dorsal radiographic projections. $A B$ : apicobasilar length of the heart; $C D$ : maximum width of the heart perpendicular to $A B$; $A I C$ : heart and inclination angle; AIT: trachea inclination angle; DPTd: distance from the right heart wall; DPTe: distance from the left heart wall; $\mathrm{H}$ : thorax vertical depth; VHS vertebral heart scale

\begin{tabular}{|c|c|c|c|c|}
\hline Variable & e Unit. & Male & \multicolumn{2}{|c|}{ Female } \\
\hline $\mathrm{AB}$ & $\mathrm{cm}(\mathrm{cv})$ & $3,70 \pm 0,25(4,41 \pm 0,30) \mathrm{A}$ & \multicolumn{2}{|c|}{$3,57 \pm 0,16(4,25 \pm 0,19) \mathrm{A}$} \\
\hline $\mathrm{CD}$ & & $2,80 \pm($ & \multicolumn{2}{|c|}{$2,83 \pm 0,18(3,37 \pm 0,21) \mathrm{A}$} \\
\hline AIC & $\left({ }^{\circ}\right)$ & $16,73 \pm 7,12$ В & \multicolumn{2}{|c|}{$22,80 \pm 8,50 \mathrm{~A}$} \\
\hline AIT & $\left({ }^{\circ}\right)$ & $9,93 \pm 3,23 \mathrm{~A}$ & \multicolumn{2}{|c|}{$8,40 \pm 0,30 \mathrm{~A}$} \\
\hline DPTd & $\mathrm{cm}$ & $0,97 \pm 0$ & \multicolumn{2}{|c|}{$1,12 \pm 0,42 \mathrm{~A}$} \\
\hline DPTe & & $0,70 \pm$ & \multicolumn{2}{|c|}{$1,02 \pm 0,43 \mathrm{~A}$} \\
\hline $\mathrm{H}$ & & $5,77 \pm 1$ & \multicolumn{2}{|c|}{$5,89 \pm 1,74 \mathrm{~A}$} \\
\hline \multirow[t]{2}{*}{ VHS } & \multirow[t]{2}{*}{$\mathrm{cV}$} & $7,75 \pm 0,48 \mathrm{~A}$ & \multicolumn{2}{|c|}{$7,61 \pm 0,34 \mathrm{~A}$} \\
\hline & & Range & Mean \pm sd & CV\% \\
\hline $\mathrm{AB} / \mathrm{CD}$ & $\mathrm{cm}(\mathrm{cv})$ & $1,14-1,45(1,18-1,21)$ & $0,07(1,08 \pm 0,06)$ & $5,52(5,5$ \\
\hline $\mathrm{AB} / \mathrm{H}$ & & $0,56-0,86(0,4)$ & $0,05(0,56 \pm 0,042$ & 7,14 \\
\hline $\mathrm{CD} / \mathrm{H}$ & & $0,48-0,70(0,40-0,58) \quad 0,54 \pm$ & $0,04(0,45 \pm 0,03)$ & $7,40(6,66)$ \\
\hline
\end{tabular}

* Means followed by different letters on the same line differ statistically. chea was inclined (AIT) at $9.93 \pm 3.23^{\circ}$ for the males and $8.4 \pm 3.94^{\circ}$ for the females and there was no significant difference between males and females $(p=0.22$. $p>0.05)$. The measured VHS showed a mean of $7.75 \pm 0.48 \mathrm{v}$ for the males and $7.61 \pm 0.34 \mathrm{v}$ for the females, and there was no difference between males and females $(p=0.73$. $p>0.05)$. Considering the whole sampled group, the AIT and VHS means were $9.82 \pm 2.73^{\circ}$ and $7.68 \pm 0.41 \mathrm{v}$, respectively.

Table 1 shows the calculation of the individual values of $\mathrm{AB}, \mathrm{CD}$ and $\mathrm{H}$, along with the $\mathrm{AB} / \mathrm{CD}, \mathrm{AB} / \mathrm{H}$ and $\mathrm{CD} / \mathrm{H}$ ratios.

\section{DISCUSSION}

Radiographically, the agouti heart presented anatomic peculiarities regarding its topography compared to other mammals. The agouti presented a significant cranial inclination of the heart $\left(16.73 \pm 7.12^{\circ}\right.$ to $\left.22.8 \pm 8.5^{\circ}\right)$ which to date has only been observed for this species. In most mammals the AIC is approximately $55^{\circ}$, with a few variations (Ware 2007). The AIC is a fundamental element in clinical medicine of wild and domestic animals because progressive increases, especially in the right ventricle, can alter the heart shape and decrease the heart angle to the sternum (Kealy et al. 2011).

There are few reports regarding the size and position of the heart in wild species and none for the agouti, but when the values reported for bats were compared (Gardner et al. 2007) in latero lateral projections, these animals presented a $45^{\circ}$ heart inclination angle, greater than that found in the present study. In guinea pigs, the heart is displaced more cranially and presents a ventral cranial inclination, the report that came closest to our findings (Heatley 2009). In the porcupine (Atelerix albiventris) a recent study suggested measurements of the heart size for the species but these authors did not define a value for the heart inclination (Black et al. 2011). In ventral dorsal projection, the agouti heart was similar to that observed in documented domestic species, such as the cat and dog (Thrall 2002) contained mostly to the left of the midline, with greater DPTd than DPTe values. The difficulty in visualizing the lung fields and CVC both in LL and VD projection were also reported for bats (Gardner et al. 2007). Although good visualization of the CVC in tamarin (Callithrix jacchus) was described in LL projection, this was not clearly identified in the VD/DV projections (Van den Broek \& Darke 1987). This difficulty in assessing the lung fields was attributed to the effect of anesthesia that induced the presence of an incomplete inspiration, that was also reported for pet monkeys (Macaca nigra and Macaca tonkeana) (Schillaci et al. 2008). The present study was carried out without requiring chemical restraint, given the cooperation and easy restraint of the agouti assessed. However, it is believed that there is some influence of the low contrast between the soft tissue structures of the thoracic cavity in these animals, regardless of the radiographic technique used. The AIC was shown to be variable, compatible with the descriptions for bats, a characteristic associated to the reflection of the head during the exam (Gardner et al. 2007).

The VHS measurements $(7.68 \pm 0.41 \mathrm{v})$ obtained were smaller than the reference values for dogs $(9.7 \pm 0.7 \mathrm{v})$ (Sle- 
eper \& Buchanan 2001) but similar to those referenced for adult cats $(7.5 \pm 0.30 \mathrm{v})$ (Litster \& Buchanan 2000). This value was also lower than the VHS measured for the tamarin $(9.42 \pm 0.44 \mathrm{v})$ (Wagner \& Kirberger 2005), porcupine (Black et al. 2011) and bat $(9.7 \pm 0.5 \mathrm{v})$ (Gardner et al., 2007), but greater than that observed in ferrets $(5.39 \pm 0.45$ - LL projection) (Onuma et al. 2009).

The $\mathrm{AB} / \mathrm{H}$ and $\mathrm{CD} / \mathrm{H}$ ratios were studied in bats (Gardner 2007) and the $A B / C D$ ratio in the porcupine (Black et al. 2011). Gardner and collaborators suggested that the $A B / H$ in bats $(1.04 \mathrm{~cm})$ contributed significantly to the increase in the heart contact with the sternum, because the heart was longer than the sternum depth in these animals. However, this relationship was not observed in the agouti studied, where the $H$ values were always greater than the $A B$ values resulting in an $\mathrm{AB} / \mathrm{H}$ ratio in the agouti $(0.56-0.86 \mathrm{~cm})$ smaller than that described by this author. Indeed, for the animals studied, the increase in the heart contact with the sternum seemed to result principally from the smaller heart inclination angle (discussed previously), compared to peer animals (Ware 2007). The $\mathrm{AB} / \mathrm{H}$ and $\mathrm{CD} / \mathrm{H}$ ratios were more sensitive to detecting heart abnormalities in sternum radiographs in bats (Gardner et al. 2007) and cats (Van den Broek \& Darke 1987). The values measured for the AB/CD ratio were slightly smaller than those observed in the porcupine $(1.38 \pm 0.11)$ and were consistent with descriptions of normal cats (Hamlin et al. 1963). The same authors suggested using the $\mathrm{AB} / \mathrm{CD}$ ratio to detect heart disease. For the agouti, the values of the variances found for these ratios suggested that these measurements can be used to predict normal heart measurements in agouti.

\section{CONCLUSIONS}

This study permitted the establishment of the first reference values for heart measurements from thoracic radiographs in agouti.

The radiographic technique without chemical restraint was well tolerated, allowing the acquisition of thoracic measurements capable of identifying alterations in heart size.

The presence of a consistent statistical sample represents the acquisition of the initial inputs for greater understanding of heart morphology in agouti, but further studies are needed to define these parameters, taking into consideration agouti with known myocardial pathology.

Acknowledgements.- The authors thank for the support of the research given by the National Council for Scientific and Technological Development $(\mathrm{CNPq})$ and the Federal University of Piauí, study and research nucleus on wild animals Núcleo de Estudos e Pesquisas com Animais Selvagens (NEPAS) for logistic support and maintaining the animals studied.

\section{REFERENCES}

Alimurung B.N., Gilbert C.A., Felner J.M. \& Schlant R.C. 1980. The influence of early repolarization variant on the exercise electrocardiogram: a correlation with coronary arteriograms. Am. Heart. J. 99:739-745.

Berllago H.G. \& Cerqueira R. 1994. Reproduction and growth of the opossum Monodelphis Domestica, Mammalia: Didelphidae, Northeastern Brazil. J. Zoo Lond. 232:551-563.
Black P.A., Marshall C., Seyfried A.W. \& Bartin A.M. 2011. Cardiac assessment of African hedgehogs, Atelerix albiventris. J. Zoo Wildl. Med. 42:4953.

Bodmer R.E., Eisenberg N. \& Redford K.H. 1997. Hunting and the likelihood of extinction of Amazonian mammals. Conservation Biology 2:460-466.

Buchanan J.W. \& Bücheler J. 1995. Vertebral scale system to measure canine heart size in radiographs. J. Am. Vet. Med. Assoc. 2:194-199.

Crissey S.D., Ange K.D., Slifka K.A., Kahn S.W.S. \& Ward A.M. 2004. Serum lipid concentrations in six canid and four ursid species in four zoos. J. Zoo Wildl. Med. 35:34-39.

Estrada A.H., Gerlach T.J., Schmidt M.K., Siegal-Willott J.L., Adrienne L., Atkins A.L., Scott B., Citino S.B. \& Padilla L.R. 2009. Cardiac evaluation of clinically healthy captive maned wolves Chrysocyon brachyurus Estrada. J. Zoo Wildl. Med. 40:478-486.

Ferraz M.S., Menezes D.J.A., Pessoa G.T., Cabral R.M., Illera M.J., Silva A.R. \& Carvalho M.A.M. 2010. Collection and evaluation of epididymal sperm in captive agoutis, Dasyprocta aguti. Theriogenology 75:459-462.

Gardner A., Thompson M.S., Fontenot D., Gibson N. \& Heard D.J. 2007. Radiographic evaluation of cardiac size in flying fox species (Pteropus rodricensis, P. hypomelanus, and P. vampyrus). J. Zoo Wildl. Med. 38:192200.

Ghadiri A., Avizeh R., Rasekh A. \& Yadegari A. 2008. Radiographic measurement of vertebral heart size in healthy stray cats. J. Feline Med. Surg. 10:61-65.

Hamlin R.L., Smetzer D.L. \& Smith G.R. 1963. Radiographic anatomy of the normal cat heart. J. Am. Vet. Med. Assoc. 143:957-961.

Heatley J.J. 2009. Cardiovascular anatomy, physiology and disease of rodent and small exotic mammals. Vet. Clin. Exot. Anim. 12:99-113.

Kealy J.K., Hester M.H. \& Graham J.P. 2011. The thorax, p.199-349. In: Kealy J.K., Hester M.H. \& Graham J.P. (Eds), Diagnostic Rradiology and Ultrasonography of the Dog and Cat. Ed. Elsevier, St Louis.

Leal I.R., Da Silva J.M.C., Tabarelli M. \& Lacher Jr T.E. 2005. Changing the course of biodiversity conservation in the caatinga of northeastern Brazil. Cons. Biol. 19:701-706.

Litster A.L. \& Buchanan J.W. 2000. Vertebral scale system to measure feline heart size in radiographs. J. Am. Vet. Med. Assoc. 216:210-214.

Lopes J.B., Cavalcante R.R., Almeida M.M., Carvalho M.A.M., Moura S.G., Dantas-Filho L.A. \& Conceição W.L.F. 2004. Desempenho de Cutias, Dasyprocta prymnolopha, criadas em cativeiro do nascimento até o desmame em Teresina, Piauí. Revta Bras. Zootec. 33:2318-2322.

Nogueira-Filho S.L.G. \& Nogueira S.S.C. 2000. Criação comercial de animais silvestres: produção e comercialização da carne e de subprodutos na região sudeste do Brasil. Revta Econ. Nordeste 31:188-195.

Pinheiro R.M., Andrade S.A. \& Cunha J.N. 1989. Preservação e exploração de animais silvestres nativos: preá, cutia e mocó. Caatinga 6:28-49.

Onuma M., Kondo H., Ono S., Ueki M., Shibuya H. \& Sato T. 2009. radiographic measurement of cardiac size in 64 ferrets. J. Vet. Med. Sci. 71:355358.

Osofsky A., Jowett P.L.H., Hosgood G. \& Tully T.N. 2001. determination of normal blood concentrations of lead, zinc, copper, and iron in Hispaniolan Amazon parrots, Amazona ventralis. J. Avian Med. Surg. 15:31-36.

Ribeiro A.S.S., Palha M.D.C., Tourinho M.M., Whiteman C.W. \& Da Silva A.S.L. 2007. Utilização dos recursos naturais por comunidades humanas do Parque Ecoturístico do Guamá, Belém, Pará. Acta Amazônica 37:235240.

Ribeiro E.E.A, Batista M.C.S, Carvalho M.A.M. \& Silva J.A.L. 2008. Hemograma e proteinograma de cutias (Dasyprocta sp.) hígidas, criadas em cativeiro: influência do sexo e da idade. Arq. Bras Med. Vet. Zootec. 60:1123-1127.

Sampaio Y. \& Batista J.E.M. 2004. Desenvolvimento regional e pressões antrópicas no bioma Caatinga, p.311-324. In: Silva J.M.C., Tabarelli M., Fonseca M.T. \& Lins L.V. (Eds), Biodiversidade da Caatinga: áreas e ações prioritárias para a conservação. Ministério do Meio Ambiente, Brasília. 
Schillaci M.A., Jones-Engel L., Heidrich J.E., Benamore R., Pereira A. \& Paul N. 2008. Thoracic radiography of pet macaques in Sulawesi, Indonesia. J. Med. Primatol. 37:141-145.

Sleeper M.M. \& Buchanan J.W. 2001. Vertebral scale system to measure heart size in growing puppies. J. Am. Vet. Med. Assoc. 219:57-59.

Stepien R.L., Benson K.G. \& Forrest L.J. 1999. Radiographic measurement of cardiac size in normal ferrets. Vet. Radiol. Ultrasound 40:606610.

Thrall D.E. 2002. Interpretation paradigms for the small animal thorax, p.318-319. In: Thrall D.E. (Ed.), Textbook of Veterinary Radiology. $4^{\text {th }}$ ed. W.B. Saunders, Philadelphia.

Wagner W.M. \& Kirberger R.M. 2005. Radiographic anatomy of the thorax and abdomen of the common marmoset (Callithrix jacchus). Vet. Radiol. Ultrasound 46:217-224.

Ware W.A. 2007. Overview of cardiac radiography, p.34-36. In: Ibid. (Ed.), Cardiovascular Disease in Small Animal. Manson Publishing, London.

Van den Broek A.H.M. \& Darke P.G.G. 1987. Cardiac measurements on thoracic radiographs of cats. J. Small Anim. Pract. 28:125-135. 